\title{
Gene Action Controlling Normalized Difference Vegetation Index in Crosses of Elite Maize (Zea mays L.) Inbred Lines
}

\author{
M.A. Adebayo ${ }^{1,2}$, A. MenKiR ${ }^{2 *}$, S. Hearne $^{3}$ and A.O. Kolawole ${ }^{1,2}$ \\ ${ }^{1}$ Department of Crop Production and Soil Science, Ladoke Akintola University of Technology, \\ Ogbomoso, Nigeria \\ ${ }^{2}$ International Institute of Tropical Agriculture (IITA), Ibadan, Nigeria \\ ${ }_{3}^{3}$ International Maize and Wheat Improvement Centre (CIMMYT), Mexico
}

(Received 19 December 2016; Accepted 17 March 2017;

Communicated by S. Gottwald)

\begin{abstract}
The quest for precise and rapid phenotyping of germplasm is increasing the interest of breeders and physiologists in the application of remote sensing techniques in maize breeding. Twenty-four drought-tolerant maize inbred lines were crossed using a modified North Carolina II mating scheme to generate 96 single-cross hybrids. The parents and the hybrids were evaluated under full irrigation and drought stress conditions in the dry seasons of 2010 and 2011 at Ikenne, southwest Nigeria. Normalized difference vegetation index (NDVI) was recorded at 3- and 8-leaf growth stages. Hybrids differed significantly for NDVI. Both general (GCA) and specific (SCA) combining ability effects were significant for NDVI measured at 8-leaf stage under both irrigation regimes, with GCA accounting for $53 \%$ of the total variation under full irrigation. Both additive and non-additive genetic effects played significant roles in the inheritance of NDVI. The females GCA effects for grain yield was positively correlated with females GCA effects for NDVI $(r=0.72, p<0.0001)$ and the male GCA effects for grain yield was also correlated with males GCA effects for NDVI $(r=0.78$, $p<0.0001)$ at 8 -leaf stage under full irrigation. These results indicate that live green biomass accumulation in maize could be identified through early screening of a large number of genotypes using NDVI for developing productive hybrids.
\end{abstract}

Keywords: Ikenne, NDVI, maize hybrids, Greenseeker, combining ability, GCA, SCA

\section{Introduction}

Maize (Zea mays L.) is an important cereal crop in the world and a primary staple in many developing countries that provides food, feed, fuel and other industrial raw materials (Morris et al. 1999; Pingali and Pandey 2000). Maize is grown in all the agro-ecological zones in Nigeria, from mangrove swamp through the rainforest lowlands to the Sudan savannah. However, the effects of climate change which include rising daily temperatures, erratic rainfall intensity and distribution, or even outright cessation of rains during main growing seasons, are making more environments where maize is being profitably grown to become increasingly vulnerable to random droughts. Annual maize yield loss 
occasioned by drought stress is estimated at 50\% in West and Central Africa (Edmeades et al. 1995) and could be above 70\% where the drought is severe and when it coincides with flowering phase in maize (Adebayo et al. 2014a). The urgency associated with tackling the rising incidence of incessant drought and its attendant consequence of huge yield loss has constrained maize breeders and physiologists to intensify efforts at adopting remote sensing devices for rapid and precise phenotyping of early breeding materials.

Remote sensing techniques have been used to estimate various crop parameters because they provide quantitative data on measured variables promptly, inexpensively and in a non-destructive manner (Price and Bausch 1995; Koller and Upadhyaya 2005; Araus et al. 2010). The use of a handheld spectroradiometer (GreenSeekerTM; NTech Industries, Ukiah, CA, USA, 2007) to assay NDVI is fast gaining prominence in maize breeding (Rouse et al. 1973; Deering 1978; Araus et al. 2010). The NDVI exploits the differential reflectance properties of crop canopy in the red and near-infrared bands, and is adjudged to be a useful spectroradiometric index for the global parameterization of vegetation-related processes because it furnishes data on canopy attributes (Koller and Upadhyaya 2005), making its application in precision phenotyping attractive. It is an index of a crop's accumulated live green biomass, or a fraction of absorbed photosynthetically active radiation (Araus et al. 2001; Reynolds et al. 2001). NDVI has been reported to be closely linked with leaf area, making it the most extensively adopted remote sensing attribute for monitoring crop productivity (Xijie 2013). The suitability of the NDVI for predicting biomass accumulation underscores its relevance as a driving force for achieving high crop productivity because high biomass accumulation has been closely connected with high yielding crop genotypes in previous studies (Teal et al. 2006; Adebayo et al. 2014b).

Early biomass in winter wheat (Triticum eastivum L.) and durum wheat (Triticum turgidum L.) as well as grain yield in soybean (Glycine max L.) have been predicted with NDVI values (Elliott and Regan 1993; Aparicio et al. 2000; Raun et al. 2001). More recent studies considered the use of NDVI for predicting grain yield potential in maize (Teal et al. 2006), sugarcane (Lofton et al. 2012), and rice at heading stage (Liu et al. 2015), stay-green effect in spring wheat (Lopes and Reynolds 2012), biomass and N content in durum wheat (Cabrera-Bosquet et al. 2011), and grassland vegetation cover in dairy farms (Bastidas et al. 2016). High broad-sense heritability values for NDVI and high genotypic correlations between NDVI and grain yield were reported in spring wheat (El-Hendawy et al. 2015) and winter wheat (Gizaw et al. 2016a, 2016b). Several studies in maize found that plant height, biomass and grain yield were correlated with the NDVI (Cabrera-Bosquet et al. 2011; Lu et al. 2012; Adebayo et al. 2014b). The use of NDVI as an efficient secondary trait for rapid phenotyping of maize germplasm for drought tolerance particularly at vegetative stage has been reported ( $\mathrm{Lu}$ et al. 2012). Romano et al. (2011) reported that an increase of water stress resulted in a reduction in leaf chlorophyll, as well as an increase in leaf senescence and biomass reduction as confirmed by NDVI. Modern breeding techniques have investigated the usefulness of the NDVI as an alternative approach for visual assessment of spot blotch disease in wheat (Kumar et al. 2016), and for mapping four QTLs for NDVI in three populations of barley (Obsa et al. 2016). 
In spite of the growing interest in precision phenotyping using NDVI, no study has examined the genetic control of NDVI in maize. Although strong relationships have been reported between grain yield and NDVI values of testcross maize hybrids developed from a common drought-tolerant maize germplasm under both full irrigation and drought stress conditions (Adebayo et al. 2014b), the contributions of the genetic components to the relationships have also not been investigated. This study was, therefore, conducted (i) to determine the gene action controlling NDVI in crosses of drought-tolerant maize inbred lines, and (ii) to assess the association between the genetic components of NDVI and grain yield under full irrigation and drought stress conditions

\section{Materials and Methods}

\section{Germplasm}

Twenty-four elite drought-tolerant maize inbred lines, twelve each from CIMMYT and IITA were selected for this study. The 24 lines were chosen form 48 genetically diverse lines previously genotyped with microsatellite markers (Adebayo et al. 2015). The lines were divided into six groups, each with four lines, and were crossed according to a North Carolina Design (NCD) II mating scheme to generate 96 single-cross hybrids. The pedigree information of the 24 inbred lines and details of hybridization processes can be found in Adebayo et al. (2014a).

\section{Field evaluation and management}

A trial composed of 96 single-crosses plus four hybrid checks was evaluated in a $10 \times 10$ triple lattices with three replications under full irrigation and drought stress conditions in the dry seasons of 2010 and 2011 at Ikenne ( $6^{\circ} 54^{\prime} \mathrm{N}, 3^{\circ} 42^{\prime} \mathrm{E}$, altitude $60 \mathrm{~m}$ ) in the rainforest of southwestern Nigeria. Details of simulation of drought stress and field maintenance of experiments can be found in Adebayo et al. (2014a). The 24 parents of the hybrids were also evaluated for per se grain yield performance in separate trials under both full irrigation and drought stress conditions. Hybrids and checks were planted in 4-m row plots spaced $0.75 \mathrm{~m}$ apart with $0.50 \mathrm{~m}$ spacing between plants within each row. Three seeds were sown per hill and later thinned to two plants per stand after emergence to attain a population density of 53,333 plants ha ${ }^{-1}$. A compound fertilizer was applied at the rates of $60 \mathrm{~kg} \mathrm{~N}, 60 \mathrm{~kg} \mathrm{P}$, and $60 \mathrm{~kg} \mathrm{~K} \mathrm{ha}^{-1}$ at the time of sowing. An additional $60 \mathrm{~kg} \mathrm{ha}^{-1} \mathrm{~N}$ was applied in the form of urea as top dressing four weeks later. Gramoxone and Primextra were applied at $5.01 \mathrm{ha}^{-1}$ each of paraquat and atrazine to control weeds. Subsequently, manual weeding was done to keep the trial weed-free.

\section{Data collection}

Normalized difference vegetation index (NDVI) was assayed on the hybrids trials at 3-leaf (two weeks after planting, 2WAP) and 8-leaf (4WAP) growth stages with the GreenSeeker ${ }^{\text {TM }}$ Handheld Optical Sensor Unit (NTech Industries, Ukiah, CA, USA). The 
readings were taken according to the procedures described in details by Adebayo et al. (2014b). The sensor head was held approximately $60 \mathrm{~cm}$ above and perpendicular to the canopy. Travel velocity through the 4-m row was at slow walking speed, enabling more than 15 NDVI measurements per row to be measured. The index was calculated as follows:

$$
\mathrm{NDVI}=\frac{(\lambda N I R-\lambda R)}{(\lambda N I R+\lambda R)}
$$

where $\lambda N I R$ is the fraction emitted near infrared radiation returned from the sensed area (reflectance) and $\lambda N$ is the fraction emitted near red radiation returned from the sensed area (reflectance).

Data recorded on plot basis on grain yield of hybrids and agronomic traits were earlier reported in Adebayo et al. (2014a). Only grain yields of the parental lines under full irrigation were presented in this report (the intensity of the stress imposed resulted in the death of most parental lines before flowering under simulated drought stress condition). Grain yield for each plot, measured in $\mathrm{kg} \mathrm{ha}^{-1}$ and adjusted to $15 \%$ moisture content, was extrapolated from grain weight and percent moisture content.

\section{Data analyses}

Separate analyses of variance (ANOVAs) were performed for NDVI measured at 3- and 8-leaf growth stages under each of full irrigation and drought stress in the dry season experiments of 2010 and 2011 to generate entry means adjusted for block effects according to the $\alpha$-lattice design. Replications, years and incomplete blocks were considered as random effects while experimental hybrids were considered fixed effects. ANOVA was then conducted for the 96 single-cross hybrids according to the NCD II (Comstock and Robinson 1948) with hybrids nested within sets over the two years. The variation among hybrids was partitioned into that due to male and female parents within sets and interaction between female and male parents pooled across sets. General combining ability (GCA) effects of both male and female parents were estimated for each line, and specific combining ability (SCA) effects were estimated as the interaction between parents. Significance of each effect was tested using the mean squares for their respective interaction with year. The mean squares due to GCA $\times$ year within sets and SCA $\times$ year within sets were tested for significance using the pooled error mean squares. All analyses were performed with PROC GLM in SAS (SAS Institute 2009) using a RANDOM statement with TEST option. The main effects of females (sets) and males (sets) represent the estimates of GCA effect, and females $\times$ males (sets) interaction represents the estimate of SCA (Hallauer and Miranda-Fo 1988). The proportional contributions of females GCA, males GCA, and SCA to the sum of squares of crosses were calculated as the ratio between the sum of squares of each component and the cross sum of squares. Line $\times$ tester analysis was calculated for NDVI_1 and NDVI_ 2 using the adjusted means after the check entries were omitted based on a method described by Kempthorne (1957). Significance of estimates of GCA and SCA effects was tested using Student's $t$-test. Pearson's correlation 
analysis was conducted between pairs of females and males GCA effects for NDVI_1 and NDVI_ 2 computed in this report and those of grain yield of the same set of maize hybrids under full irrigation and drought stress earlier reported in Adebayo et al. (2014a) using PROC CORR in SAS (SAS Institute 2009).

\section{Results}

Results of analysis of variance combined over two years for NDVI_1 and NDVI_2 under both full irrigation and drought stress are presented in Table 1. Year and hybrids (sets) were significant sources of variation for NDVI_1 and NDVI_2 under full irrigation and drought stress conditions (Table 1). Under full irrigation, significant variation was observed for females (sets) $\times$ year interaction for NDVI_1 whereas males (sets), and females $\times$ males (sets) interaction were significant sources of variation for NDVI_2 (Table 1). Under drought stress, males (sets), and females $\times$ males (sets) $\times$ year interaction

Table 1. Mean squares of NDVI from the combined analyses of variance for the 96 single-cross hybrids and four checks evaluated under full irrigation and drought stress at Ikenne in Nigeria in the dry seasons of 2010 and 2011

\begin{tabular}{|c|c|c|c|}
\hline Source of variation & Df & NDVI at 3-leaf stage & NDVI at 8-leaf stage \\
\hline \multicolumn{4}{|l|}{ Full-irrigation environment } \\
\hline Year & 1 & $0.5 * * *$ & $3.7 * *$ \\
\hline Sets & 5 & 0.003 & $0.1 *$ \\
\hline Hybrids (Sets) & 99 & $9.1 * * *$ & $15.5 * * *$ \\
\hline Females (Sets) & 18 & 0.001 & 0.01 \\
\hline Males (Sets) & 18 & 0.0004 & $0.02 * *$ \\
\hline Females $\times$ Males (Sets) & 54 & 0.0004 & $0.01 *$ \\
\hline Females (Sets) $\times$ Year & 18 & $0.001 * *$ & 0.01 \\
\hline Males (Sets) $\times$ Year & 18 & 0.0002 & 0.004 \\
\hline Females $\times$ Males $($ Sets $) \times$ Year & 54 & 0.0003 & 0.004 \\
\hline \multicolumn{4}{|l|}{ Drought stress environment } \\
\hline Year & 1 & $0.3^{* *}$ & $0.6^{*}$ \\
\hline Sets & 5 & 0.001 & $0.1 * *$ \\
\hline Hybrids (Sets) & 99 & $9.2^{*}$ & $30.1 * * *$ \\
\hline Females (Sets) & 18 & 0.0003 & $0.02 *$ \\
\hline Males (Sets) & 18 & $0.001 *$ & 0.02 \\
\hline Females $\times$ Males (Sets) & 54 & 0.0005 & $0.01 *$ \\
\hline Females (Sets) $\times$ Year & 18 & 0.0003 & 0.01 \\
\hline Males (Sets) $\times$ Year & 18 & 0.0004 & $0.01 * *$ \\
\hline Females $\times$ Males $($ Sets $) \times$ Year & 54 & $0.001 *$ & 0.004 \\
\hline
\end{tabular}

$*, * *, * * *$ : significantly different from zero at $p<0.05,0.01$, and 0.001 , respectively. 
differed significantly for NDVI_1 whereas females (sets), females $\times$ males (sets), and males (sets) $\times$ year interaction exhibited significant differences for NDVI_2 (Table 1). Results of partitioning hybrid sum of squares for grain yield in a previous study (Adebayo et al. 2014a) and for NDVI_1 and NDVI_2 in the present study revealed that the GCA sum of squares for females accounted for a greater proportion of the total variation than the GCA sum of squares for males in grain yield and NDVI_1. However, the GCA sum of squares for males were greater than the GCA sum of squares for females in NDVI_2 (Fig. 1). Overall, both GCA and SCA accounted for 50\% of the total variation in NDVI_1 whereas GCA accounted for 53 and $67 \%$ of the total variations in NDVI_2 and grain yield, respectively, indicating that the GCA:SCA ratio was 1.0 for NDVI_ $\overline{1}$ but greater than unity for grain yield and NDVI_2 (Fig. 1).

Under full irrigation, one inbred line from CIMMYT (EXL06) and three IITA (ADL38, ADL41 and ADL47) lines had positive and significant GCA effects for NDVI_1 when used in crosses as female parents whereas four CIMMYT (EXL02, EXL03, EXL16 and EXL17) and one IITA (ADL41) lines had positive and significant GCA effects for NDVI_1 when used in crosses as male parents (Table 2). For NDVI_2, seven CIMMYT and two IITA (ADL41 and ADL47) inbred lines had positive and significant GCA effects when used in crosses as males whereas one CIMMYT (EXL06) and five IITA lines had positive and significant GCA effects when used in crosses as females (Table 2). Only one CIMMYT (EXL06) and two IITA (ADL41 and ADL47) lines had significant GCA effects for both NDVI_1 and NDVI_2 when used as female parents. Also, three CIMMYT (EXL02, EXL03 and EXL17) and one IITA (ADL41) lines had significant GCA effects for both NDVI_1 and NDVI_2 when used as male parents (Table 2). Similar results were

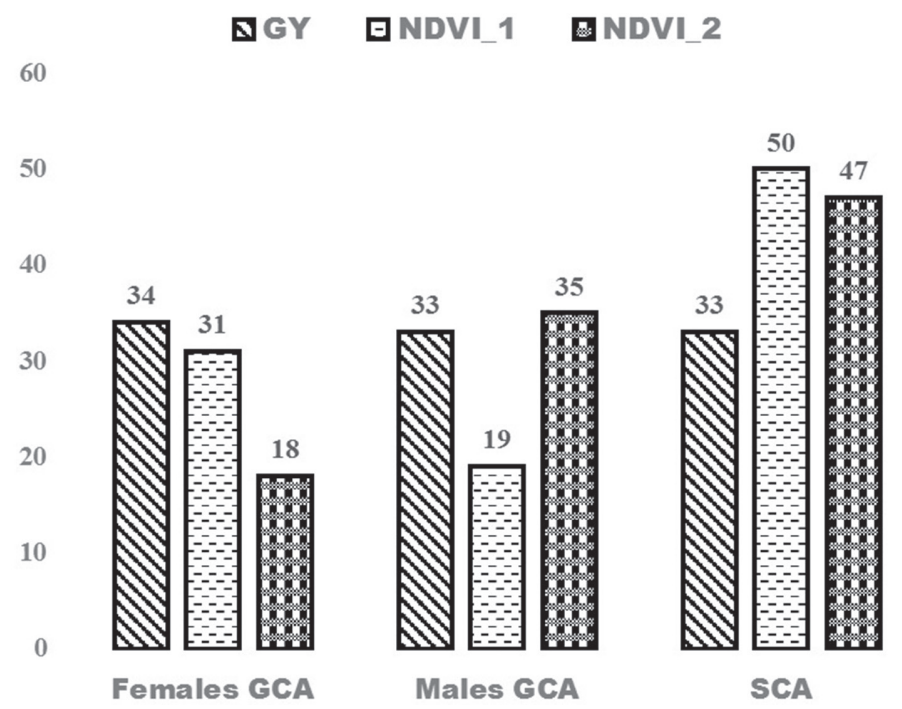

Figure 1. Contributions of females GCA, males GCA, and SCA to the sums of squares for grain yield $\left(\mathrm{GY}\right.$ in $\mathrm{kg} \mathrm{ha}^{-1}$ ), and NDVI measured at 3- and 8-leaf growth stages 


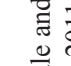

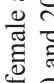

$\underset{4}{4}$

응

学

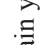

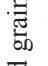

를

बू

焉

5

क⿺⿻一⿰冫⿰亅⿱丿丶丶

प्त

$\frac{0}{1}$

들

ते के

ह

己ृ

造

$\exists$ 물

字。

อั.

苞.

巡

¿

ن

莺尝

का d

:

로

¿

진

D $\frac{1}{b}$

प्रु

\&) 으

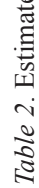

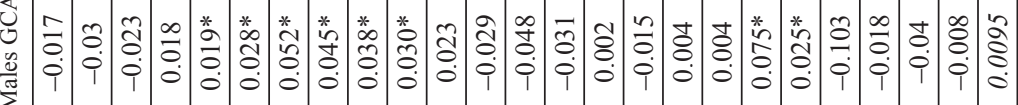
$N_{1}$

㝵

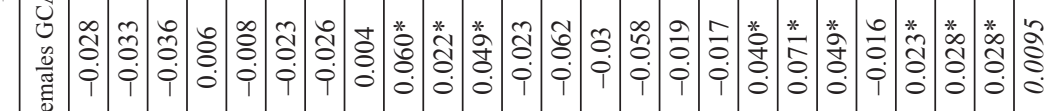

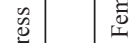

$\pm$

官

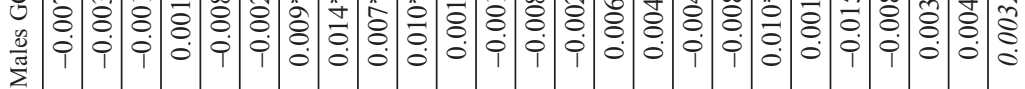
$=$

点

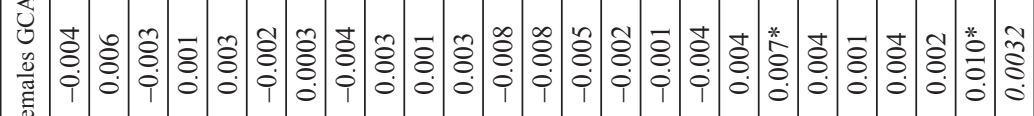
近

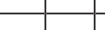

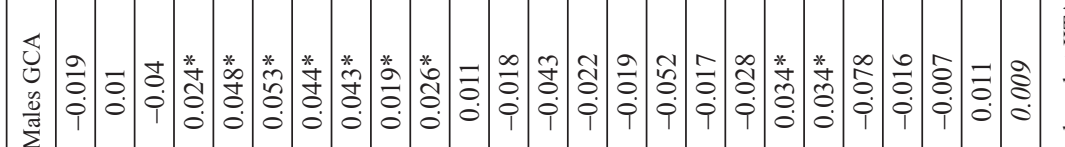
$\mathrm{N}$

5

苮

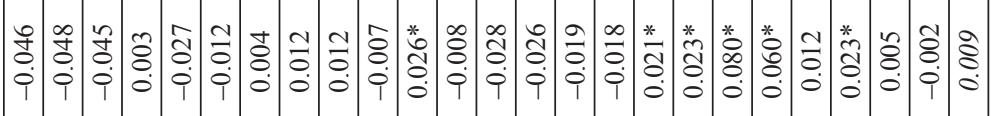
要

总

总

.믐

声

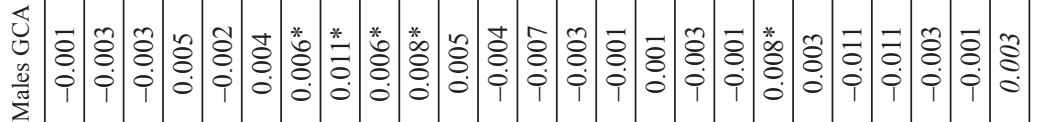
.

字

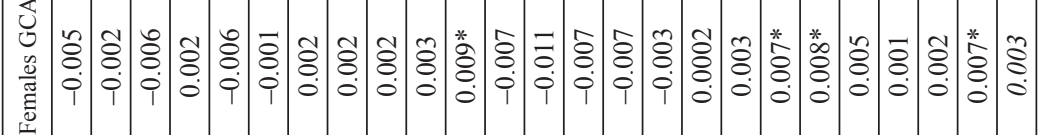

它完

$\sum^{\infty}$

专

प्ष

टे 
Table 3. Pearson's correlation analysis involving GCA effects for NDVI measured at 3- and 8-leaf growth stages and grain yield of female and male parents of 96 single-cross hybrids evaluated under full irrigation and drought stress conditions in the dry seasons of 2010 and 2011 in Nigeria

\begin{tabular}{|c|c|c|c|c|c|}
\hline \multirow{2}{*}{} & \multicolumn{3}{|c|}{ Grain yield } \\
\cline { 3 - 6 } & \multicolumn{2}{|c|}{ Full irrigation } & \multicolumn{2}{c|}{ Drought stress } \\
\cline { 2 - 6 } & Females & Males & Females & Males \\
\hline \multirow{2}{*}{ NDVI_1 } & Females & $0.635^{* *}$ & 0.246 & 0.383 & -0.024 \\
\cline { 2 - 6 } & Males & 0.111 & $0.644^{* *}$ & 0.264 & $0.409^{*}$ \\
\hline \multirow{2}{*}{ NDVI_2 } & Females & $0.715^{* * *}$ & 0.129 & $0.625^{* *}$ & $0.625^{* *}$ \\
\cline { 2 - 6 } & Males & 0.278 & $0.775^{* * *}$ & $0.528^{* *}$ & $0.626^{* *}$ \\
\hline
\end{tabular}

$*, * *, * * *$ Correlation coefficient $(r)$ significantly different from zero at $p<0.05,0.01$, and 0.0001 , respectively. NDVI_1 and NDVI_2 = NDVI measured at 3- and 8-leaf growth stages, respectively.

recorded under drought stress. Amongst the 24 parents, two CIMMYT (EXL02 and EXL06) and two IITA (ADL41 and ADL47) lines had significant GCA effects for NDVI_1 and NDVI_2 when used in crosses as either males or females, or both parents under full irrigation and drought stress conditions. The four inbred lines produced above $1,000 \mathrm{~kg}$ $\mathrm{ha}^{-1}$ grain yield under full irrigation (data not shown).

Pearson's correlation analysis revealed significant relationships between grain yield and each of NDVI_2 $(r=0.64, p<0.0001)$ and NDVI_1 $(r=0.43, p<0.0001)$ under full irrigation. Grain yield had weaker correlations with NDVI_2 $(r=0.51, p<0.0001)$ and NDVI_1 $(r=0.25, p<0.05)$ under drought stress. Correlation of the general combining ability effects of female and male parents for grain yield and NDVI revealed that female GCA effects for NDVI_2 was correlated $(r=0.72, p<0.0001)$ with female GCA effects for grain yield and the male GCA effects for NDVI_2 was also correlated $(r=0.78$, $p<0.0001$ ) with male GCA effects for grain yield under full irrigation. Similarly, the female and male GCA effects for NDVI_2 were correlated $(r=0.63, p<0.01)$ with female and male GCA effects for NDVI_2 under drought stress (Table 3). Significant correlations were also recorded between female GCA effects for NDVI_2 and male GCA effects for grain yield, and vice versa, under drought stress only (Table 3).

\section{Discussion}

\section{Combined analyses of variance and estimation of genetic parameters for NDVI}

Normalized difference vegetation index (NDVI) has been used extensively as a proxy trait for assessing live green biomass during vegetative stage in a non-destructive way and as a potentially useful secondary trait in maize breeding (Teal et al. 2006; Marti et al. 2007; Inman et al. 2008; Araus et al. 2010; Lu et al. 2012). Understanding the gene action controlling the NDVI is important for achieving significant advances in biomass accumulation in hybrid maize. Equal contribution of GCA and SCA effects to the observed vari- 
ation in NDVI at the 3-leaf growth stage under full irrigation in this study suggests that the mode of inheritance of this trait could be both additive and non-additive. As the hybrids progressed to the 8-leaf growth stage, additive genetic effects became more prominent than non-additive genetic effects for NDVI, suggesting that genes with additive effects played a greater role in the inheritance of NDVI at this stage. Additive gene action has been reported to be more preponderant than non-additive gene action in the inheritance of other important agronomic traits such as plant height, days to silking, number of ears per plant, plant and ear aspects, and grain yield in maize (Derera et al. 2008; Dhliwayo et al. 2009; Adebayo et al. 2014a). The two CIMMYT (EXL06 and EXL16) and two IITA (ADL41 and ADL47) inbred lines that had positive and significant GCA effects for NDVI under full irrigation alongside two other CIMMYT (EXL02 and EXL03) lines under drought stress can be used as sources of useful genes with additive effects for developing new populations to extract more productive inbred lines with improved biomass production. The significant SCA effects for NDVI and its sizeable contribution to total sums of squares indicate that genes with non-additive effects could also play a prominent role in the inheritance of the trait, making identification of hybrids with high biomass accumulation at vegetative stage feasible. The absence of significant females $\times$ year, males $\times$ year, and females $\times$ males $\times$ year interactions for NDVI at 8 -leaf growth stage under full irrigation suggests that parental lines and hybrids with high green biomass accumulation were relatively consistent across years in this study. Contrasting reports were given in earlier studies about the effects of two- and three-way interactions on important agronomic traits (Meseka et al. 2006; Derera et al. 2008) suggesting that observed responses are definite properties of individual germplasms.

\section{Correlations of grain yield and NDVI, and their genetic components}

In agreement with previous workers (Teal et al. 2006; Adebayo et al. 2014b), we found a significant correlation between NDVI and grain yield. However, the relationship was stronger under full irrigation than under drought stress, corroborating earlier findings by Adebayo et al. (2014b). This suggests that NDVI is more predictive of grain yield in maize under optimal or full irrigation conditions. Hence, efficient management of water resources for irrigation purposes in drought-prone agro-ecologies is imperative for sustainable global agricultural development (Valipour 2013a, b, c, 2016; Zhao et al. 2015). Maximum biomass accumulated at a later stage of development in cereals has been linked to improved biomass at early stage of development (Cabrera-Bosquet et al. 2011). It thus appears that maize hybrids that accumulate more shoot biomass at the seedling stage have the propensity of producing high grain yield at harvest. This is partly because NDVI has been associated with leaf area which is a functional part of photosynthesis that contributes to final grain yield in maize (Lu et al. 2012). The strong associations observed between GCA effects for both parents for grain yield and the GCA effects for both parents for NDVI particularly at 8-leaf stage under both irrigation regimes suggest that additive genes play significant roles in high biomass accumulation at the seedling stage and grain yield productivity in maize. The corresponding relationship of female to female GCA ef- 
fects on the one hand, and male to male GCA effects on the other, between grain yield and NDVI may also suggest the need for selecting suitable inbred lines as female and male parents for developing productive hybrids.

It should be noted that the differences in ANOVA results of NDVI under full irrigation and drought stress conditions in this study are principally caused by variation in the prevailing edaphic factors in the two blocks rather than the effects due to simulated drought stress. This is because the NDVI readings were taken in the two blocks - full irrigation and drought stress - before the simulation of drought stress. However, the stronger correlation observed between grain yield recorded under full irrigation vis-à-vis the grain yield recorded under simulated drought stress at harvest and NDVI recorded at seedling stages supported earlier reports that NDVI is more predictive of grain yield under optimum growing conditions (Adebayo et al. 2014b). Maize inbred lines with high and significant additive genetic effects for NDVI can be selected in breeding programs to develop source populations for high NDVI. Also, the high yield potential of these inbred lines suggests that they could be suitable parents for developing hybrids in breeding populations. The mode of inheritance of live green biomass at the early seedling stage of maize hybrids observed in the present study provides an indication of the possibility of rapid screening of a large number of maize genotypes to make rapid gain in hybrid maize breeding.

\section{References}

Adebayo, M.A., Menkir, A., Blay, E., Gracen, V., Danquah, E., Hearne, S. 2014a. Genetic analysis of drought tolerance in adapted $\times$ exotic crosses of maize inbred lines under managed stress conditions. Euphytica 196:261-270.

Adebayo, M.A., Menkir, A., Hearne, S. 2014b. Relationships between normalized difference vegetation index (NDVI) and other traits of tropical testcross maize (Zea mays L.) hybrids under drought and well-watered conditions. J. Appl. Agric. Res. 6:173-180.

Adebayo, M.A., Menkir, A., Malaku, G., Blay, E., Gracen, V., Danquah, E., Ladejobi, O. 2015. Diversity assessment of drought tolerant exotic and adapted maize inbred lines with microsatellite markers. J. Crop Sci. Biotech. 18:147-154.

Aparicio, N., Villegas, D., Casadesus, J., Araus, J.L., Royo, C. 2000. Spectral vegetation indices as nondestructive tools for determining durum wheat yield. Agron. J. 92:83-91

Araus, J.L., Casadesús, J., Bort, J. 2001. Recent tools for the screening of physiological traits determining yield. In: Reynolds, M.P., Ortiz-Monasterio, J.I., McNab, A. (eds), Application of Physiolograin Yield in Wheat Breeding. CIMMYT. Mexico. pp. 59-77.

Araus, J.L., Sanchez, C., Cabrera-Bosquet, L. 2010. Is heterosis in maize mediated through better water use? New Phytologist 187:392-406.

Barker, D.W., Sawyer, J.E. 2010. Using active canopy sensors to quantify corn nitrogen stress and nitrogen application rate. Agron. J. 102:964-971.

Bastidas, A.D., Barahona, R.R., Cerón-Muñoz, M. 2016. Variation in the normalized difference vegetation index (NDVI) in dairy farms in northern Antioquia. Livestock Research for Rural Development. LRDR Newsletter 28(3) http://www.lrrd.org/lrrd28/3/bast28043.html

Cabrera-Bosquet, L, Molero, G., Stellacci, A.M., Bort, J., Nogués, S., Araus, J.L, Cabrera-Bosquet, L., Molero, G., Stellacci, A.M., Bort, J., Nogués, S., Araus, J.L. 2011. NDVI as a potential tool for predicting biomass, plant nitrogen content and growth in heat genotypes subjected to different water and nitrogen conditions. Cereal Res. Commun. 39:147-159. 
Comstock, R.E., Robinson, H.F. 1948. The components of genetic variance in population of biparental progenies and their use in estimating the average degree of dominance. Biometrics 4:254-266.

Deering, D.W. 1978. Rangeland reflectance characteristics measured by aircraft and spacecraft sensors. Ph.D. diss. Texas A\&M Univ., College Station, USA.

Derera, J., Tongoona, P., Vivek, B.S., Laing, M.D. 2008. Gene action controlling grain yield and secondary traits in southern African maize hybrids under drought and non-drought environments. Euphytica 162:411422.

Dhliwayo, T., Pixley, K., Menkir, A., Warburton, M. 2009. Combining ability, genetic distances, and heterosis among elite CIMMYT and IITA tropical maize inbred lines. Crop Sci. 49:1201-1210.

Edmeades, G.O., Bänziger, M., Chapman, S.C., Ribaut, J.M., Bolaños, J. 1995. Recent advances in breeding for drought tolerance in maize. In: Badu-Apraku, B. (ed.), Contributing to Food Self-sufficiency: Maize Research and Development in West and Central Africa. Proc. of a Regional Maize Workshop, 28 May-2 June 1995. IITA. Ibadan, Nigeria. pp. 24-41

El-Hendawy, S., Al-Suhaibani, N., Salem, A.E., Ur Rehman, S., Schmidhalter, U. 2015. Spectral reflectance indices as a rapid and nondestructive phenotyping tool for estimating different morphophysiological traits of contrasting spring wheat germplasms under arid conditions. Turkish J. of Agric. and Forestry 39:1-16.

Elliott, G.A., Regan, K.L. 1993. Use of reflectance measurements to estimate early cereal biomass production on sandplain soils. Austr. J. Exp. Agric. 33:179-183.

Gizaw, S.A., Garland-Campbell, K., Cartera, A.H. 2016a. Use of spectral reflectance for indirect selection of yield potential and stability in Pacific Northwest winter wheat. Field Crops Res. 196:199-206.

Gizaw, S.A., Garland-Campbell, K., Cartera, A.H. 2016b. Evaluation of agronomic traits and spectral reflectance in Pacific Northwest winter wheat under rain-fed and irrigated conditions. Field Crops Res. 196:168179.

Hallauer, A.R., Miranda-Fo, J.B. 1988. Quantitative Genetics in Maize Breeding. 2nd edn. Iowa State University Press. Ames, IO, USA.

Inman, D., Khosla, R.., Reich, R.M., Westfall, D.G. 2008. Normalized difference vegetation index and soil color-based management zones in irrigated maize. Agron. J. 100: 60-66.

Kempthorne, O. 1957. An Introduction to Genetic Statistics. John Wiley and Sons, Inc. New York, USA.

Koller, M., Upadhyaya, S.K. 2005. Relationships between modifies normalized vegetation index and leaf area index for processing tomato. Appl. Engin. in Agric. 21:927-933.

Kumar, S., Roder, M.S., Singh, R.P., Kumar, S., Chand, R., Joshi, A.K., Kumar, U. 2016. Mapping of spot blotch disease resistance using NDVI as a substitute to visual observation in wheat (Triticum aestivum L.). Mol. Breed. 36:95.

Liu, K., Li, Y., Hu, H., Zhou, L., Xiao, X., Yu, P. 2015. Estimating rice yield based on normalized difference vegetation index at heading stage of different nitrogen application rates in southeast of China. J. of Environ. and Agric. Sci. 2:13.

Lofton, J., Tubana, B.S., Kanke, Y., Teboh, J., Viator, H., Dalen, M. 2012. Estimating sugarcane yield potential using an in-season determination of normalized difference vegetative index. Sensors 12:7529-7547.

Lopes, M.S., Reynolds, M.P. 2012. Stay-green in spring wheat can be determined by spectral reflectance measurements (normalized difference vegetation index) independently from phenolograin yield. J. Exp. Bot. 63:3789-3798.

Lu, Y., Xu, J., Yuan, Z., Hao, Z., Xie, C., Li, X., Shah, T., Lan, H., Zhang, S., Rong, T., Xu, Y. 2012. Comparative LD mapping using single SNPs and haplotypes identifies QTL for plant height and biomass as secondary traits of drought tolerance in maize. Mol. Breed. 30:407-418.

Marti, J., Bort, J., Slafer, G.A., Araus, J.L. 2007. Can wheat yield be assessed by early measurements of NDVI? Ann. Appl. Biol. 150:253-257.

Meseka, S.K., Menkir, A., Ibrahim, A.E.S., Ajala, S.O. 2006. Genetic analysis of performance of maize inbred lines selected for tolerance to drought under low nitrogen. Maydica 51:487-495.

Morris, M.L., Risopoulos, J., Beck, D. 1999. Genetic changes in farmer-recycled maize seed; a review of the evidences. CIMMYT Economics Working Paper No. 99-07. CIMMYT. Mexico. 
NTech Industries. 2007. Model 505 Greenseeker handheld optical sensor unit operating manual. Available at http://www.ntechindustries.com/lit/gs/GS_Handheld_Manual_rev_K.pdf (verified 18 Jan. 2016). NTech Industries, Ukiah, CA, USA.

Obsa, B.T., Eglinton, J., Coventry, S., March, T., Langridge, P., Fleury, D. 2016. Genetic analysis of developmental and adaptive traits in three doubled haploid populations of barley (Hordeum vulgare L.). Theor. Appl. Genet. 129:1139-1151.

Pingali, P.L., Pandey, S. 2000. World maize needs meeting: technological opportunities and priorities for the public sector, In: Pingali, P.L. (ed.), 1999-2000 World Maize Facts and Trends. CIMMYT, Mexico. pp. 1-3.

Price, J.C., Bausch, W.C. 1995. Leaf area index estimation from visible and near-infrared reflectance data. Remote Sens. Environ. 52:55-65.

Raun, W.R., Johnson, G.V., Stone, M.L., Sollie, J.B., Lukina, E.V., Thomason, W.E., Schepers, J.S. 2001. In-season prediction of potential grain yield in winter wheat using canopy reflectance. Agron. J. 93:131138.

Reynolds, M.P., Trethowan, R.M., van Ginkel, M., Rajaram, S. 2001. Application of physiolograin yield in wheat breeding. In: Reynolds, M.P., Ortiz-Monasterio, J.I., McNab, A. (eds), Application of Physiolograin Yield in Wheat Breeding. CIMMYT. Mexico. pp. 2-10.

Romano, G., Zia, S., Sanchez, C., Araus, J.L., Müller, J. 2011. Use of thermography for high throughput phenotyping of tropical maize adaptation in water stress. Computers and Electronics in Agric. 79:67-74.

Rouse, J.W., Haas, R.H., Schell, J.A., Deering, D.W. 1973. Monitoring vegetation systems in the Great Plains with ERTS. In: Third ERTS Symposium, NASA SP-351. NASA, Washington, D.C., USA, Vol. 1, pp. 309-317.

SAS Institute 2009. SAS Proprietary Software Release 9.2. SAS Institute, Inc., Cary, NC, USA.

Teal, R.K., Tubana, B., Girma, K., Freeman, K.W., Arnall, D.B., Walsh, O., Raun, W.R. 2006. In-season prediction of corn grain yield. Potential using normalized difference vegetation index. Agron. J. 98:1488-1494.

Valipour, M. 2013a. Necessity of irrigated and rainfed agriculture in the world. Irrigation and Drainage Systems Engineering S9: e001.

Valipour, M. 2013b. Evolution of irrigation-equipped areas as share of cultivated areas. Irrigation and Drainage Systems Engineering 2: e114.

Valipour, M. 2013c. Increasing irrigation efficiency by management strategies: cutback and surge irrigation. ARPN J. of Agric. and Biol. Sci. 8:35-43.

Valipour, M. 2016. How much meteorological information is necessary to achieve reliable accuracy for rainfall estimations? Agriculture 6:53.

Xijie, L. 2013. Remote sensing, normalized difference vegetation index (NDVI), and crop yield forecasting. M.Sc. Thesis, University of Illinois at Urbana-Champaign, IL, USA. 163 p.

Zhao, J., Xu, Z., Zuo, D., Wang, X. 2015. Temporal variations of reference evapotranspiration and its sensitivity to meteorological factors in Heihe River Basin, China. Water Sci. and Engin. 8:1-8. 